\title{
Anti-inflammatory effect of oligostilbenoids from Vitis heyneana in LPS-stimulated RAW 264.7 macrophages via suppressing the NF-KB activation
}

Do Thi Ha ${ }^{1 *}$, Phung Thanh Long ${ }^{1}$, Tran Thi Hien ${ }^{2,3}$, Dao Trong Tuan ${ }^{4}$, Nguyen Thi Thuy An ${ }^{1,5}$, Nguyen Minh Khoi ${ }^{1}$, Ha Van Oanh ${ }^{6}$ and Tran Manh Hung ${ }^{7^{*}}$

\begin{abstract}
Background: Vitis heyneana is widely distributed in the north of Vietnam, it has been used in Vietnamese traditional medicine as an agent for treatment of arthritis, bronchitis, carbuncles and inflammatory conditions, and menstrual irregularities. However, this plant has not been investigated in phytochemical constituents and biological effects, especially in the anti-inflammatory property.

Results: Bioassay-guided fractionation of the EtOAc soluble fraction from the aerial part of Vitis heyneana resulted in

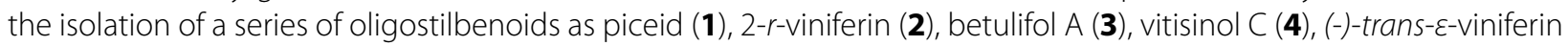
(5), a-viniferin (6), shoreaketon (7), amurensin B (8), vitisinol B (9), and cis-vitisin B (10). Compound $\mathbf{5}$ showed the most potent inhibitory activities by suppressing LPS-induced COX-2 expression and PGE2 production. This compound exhibited significantly reduced LPS-induced nitric oxide (NO) release in a dose-dependent manner. These effects are accompanied with the inhibition of transcription factor NF-KB activation.
\end{abstract}

Conclusion: The results suggested that trans- $\varepsilon$-viniferin exerts anti-inflammatory effects via suppression the NF-KB activation in RAW 264.7 cells.

Keywords: Vitis heyneana, (-)-Trans-e-viniferin, COX-2, PGE2, NO, NF-kB

\section{Background}

The genus Vitis (family Vitaceae) is in the major group with more than 66 species identified and is distributed throughout the world [1]. In Vietnam, 6 species of Vitis genus have been reported until now, including $V$. larbusca L., $V$. heyneana Roem, \& Schult., $V$. retordii Roman du Caill. Ex Planch. V. vinifera L., V. balansana Planch., V. flexuosa Thunb [2]. Typical constituents in Vitis genus have been reported to be oligomers of

\footnotetext{
*Correspondence: hado.nimms@gmail.com; hung.tran@vnuk.edu.vn ${ }^{1}$ Vietnam National Institute of Medicinal Materials, 3B Quangtrung, Hanoi, Vietnam

${ }^{7}$ Department of Biomedical Sciences, Institute for Research and Executive Education (VNUK), The University of Danang, 41 Le Duan, Haichau district, Danang 551000, Vietnam

Full list of author information is available at the end of the article
}

resveratrol named stilbenoids [3-7]. To date, over 1000 stilbenoids have been identified in various plant families such as Celastraceae, Cyperaceae, Fabaceae, Iritaceae, Moraceae, Paeoniaceae, and Vitaceae. The Vitaceae family includes about 900 species within 14-17 genera, primarily in tropical climate $[8,9]$. Of these genera, only five, the Ampelopsis, Cissus, Cyphostemma, Parthenocissus, and Vitis genera reported the presence of stilbenoids. However, chemical constituents of the species in Vitis genus have been studied the most. Stilbenoids possessed various pharmacological activities such as antioxidative, anti-inflammatory, and antimicrobial activities, as well as having cardioprotective, hepatoprotective, and neuroprotective effects [10-14]. Although approximately 100 stilbenoid monomers, dimers, and oligomers have been found in all Vitis species, research 
on the chemical compositions and biological activities of Vitis genus remains lacking [15]. Our screening antiinflammatory effect of an ethanol extract of 4 Vitis species including V. heyneana Roem. \& Schult. (VH), Vitis vinifera L. (VV); Vitis balansana Planch. (VB), and Vitis labrusca L. (VL) collected in Vietnam via suppression of LPS-induced COX-2 expression found that $96 \%$ of ethanol extract of $\mathrm{VH}$ exhibited the most activity [16]. Besides, $V$. heyneana is widely distributed in northern Vietnam, for example in Cao Bang, Lang Son, and Lao Cai provinces. The stems and roots of this species are traditionally used for the treatment of arthritis, bronchitis, carbuncles and inflammatory conditions, and menstrual irregularities in Vietnamese indigenous peoples [17]. So far, few studies have been done to investigate the chemical constituents of $\mathrm{VH}$. Currently, only a few studies have referred to the presence of stilbenoids in $\mathrm{VH}$ [17-19]. However, evaluation of anti-inflammatory activities of the $\mathrm{VH}$ species have not been studied yet. This study reports the anti-inflammatory effects of $\mathrm{VH}$ extracts and its isolated oligostilbenoids via suppressing LPS-induced COX-2 expression, PGE2 and NO productions, and NF- $\mathrm{kB}$ activation in RAW 264.7 macrophages.

\section{Results and discussion}

\section{Screening inhibitory activities}

To study the cytotoxic effects of extract and its fractions on cell viability, the RAW 264.7 cells were incubated and treated a concentration of all materials $(50 \mu \mathrm{g} / \mathrm{mL})$. The results showed that all the extract and fractions that induced cell toxicities were negligible at the above concentrations [16]. In order to examine candidate extract/ fractions inhibiting COX-2 in RAW 264.7 cells, ethanol $V$. heyneana extract $(\mathrm{VH})$ and its fractions (n-hexane$\mathrm{VHH}$, ethyl acetate-VHE and water-VHW) were tested on COX-2 mRNA expression level by qPCR. As shown in Fig. 1, the inhibitory effect of COX-2 mRNA was mostly potently suppressed by VHE and VH.

\section{Structure identification of the isolated compounds}

To investigate the active components from the potential fraction, several chromatographic techniques were applied and ten compounds were obtained after purification. On the basis of NMR spectroscopic analysis, and in comparison with the previous studies, the chemical structures of these compounds were identified as piceid (1), 2-r-viniferin (2), betulifol A (3), vitisinol C (4), (-)-trans- $\varepsilon$-viniferin (5), $\alpha$-viniferin (6), shoreaketon (7), amurensin B (8), vitisinol B (9), and cis-vitisin B (10) (Fig. 2) [17, 20-26].

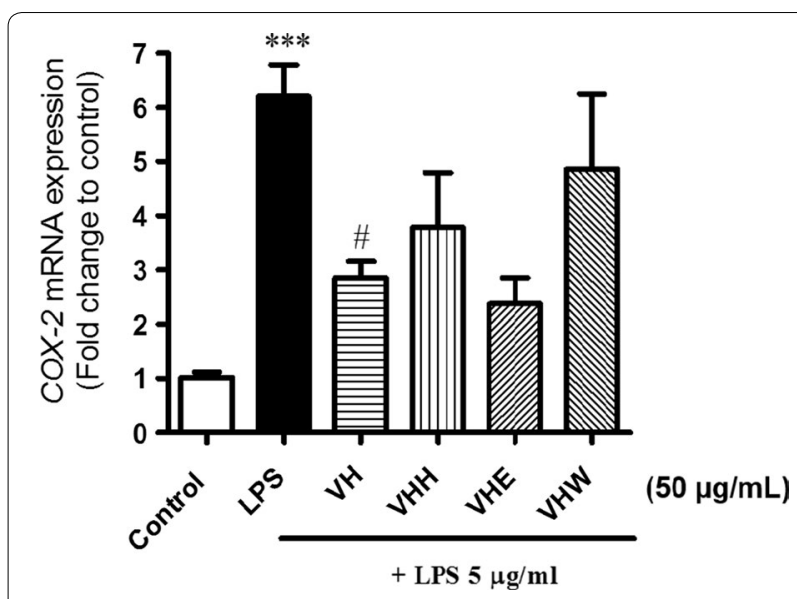

Fig. 1 COX-2 expression effects of $V$. heyneana extract $(\mathbf{V H})$ and its fractions (VHH: $n$-hexane, VHE: ethyl acetate, VHW: water fraction; all $50 \mu \mathrm{g} / \mathrm{mL})$. Eighteen hours after treating cells with LPS $(5 \mu \mathrm{g} / \mathrm{mL})$ with or without fractions in RAW 264.7 cells. Samples were harvested and lysated for COX-2 mRNA level by qPCR. Relative changes in the COX-2 mRNA expression ( ${ }^{*}$ significant as compared to control, ${ }^{*}, p<0.05$; ${ }^{* *}, p<0.01$; ${ }^{* *}, p<0.001$; ${ }^{*}$ significant as compared to LPS group, $\mathrm{n}=4-5)$

\section{Screening inhibitory activities of oligostilbenoids} by suppressing LPS-induced COX-2 expression and PGE2 production in RAW 264.7 macrophages

The effects of all isolated compounds at concentration of $10 \mu \mathrm{M}$, and a reference agent, meloxicam $(20 \mu \mathrm{M})$ were further examined on LPS-induced COX-2 protein, mRNA expression and LPS-induced PGE2 production in RAW 246.7 cells by reported method with slight modification. As the results in Fig. 3, western blotting and real time-PCR assays revealed that, among the active metabolites, trans- $\varepsilon$-viniferin $(5 ; 10 \mu \mathrm{M})$ potently suppressed LPS-induced COX-2 expression in RAW 246.7 cells (Fig. 3a, b). Furthermore, ELISA assay confirmed that $\mathbf{5}$ most inhibited the level of LPS-induced PGE2 production in RAW 264.7 cells (Fig. 3c).

\section{Effects of 5 on COX-2, iNOS expression and PGE2 production in RAW 264.7 macrophages}

Considering that the $\mathbf{5}$ was the most active metabolite, the effects of this compound was investigated on LPSinduced PGE2 production in RAW 264.7 cells using ELISA method with slight modification. As the results in Fig. 4a show, stimulation of cells resulted in the increase of PGE2 production compared with unstimulated vehicle cells. In the administration of $5(1-30 \mu \mathrm{M})$, the PGE2 productions were remarkably reduced in a concentration dependent manner $(p<0.05)$. We further investigated whether the inhibition effect by the same range of concentration of $\mathbf{5}$ was related to the gene expression, 


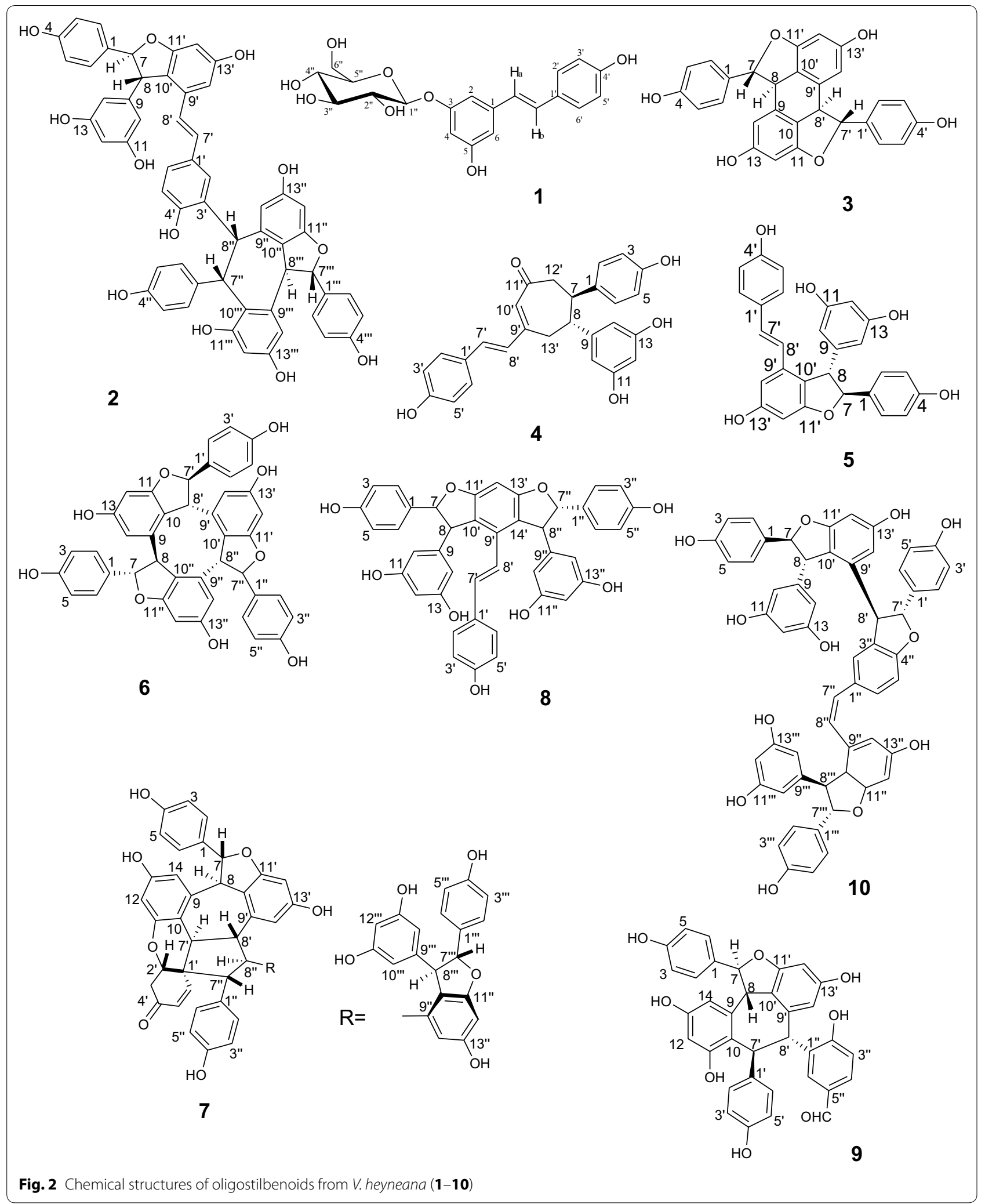


a

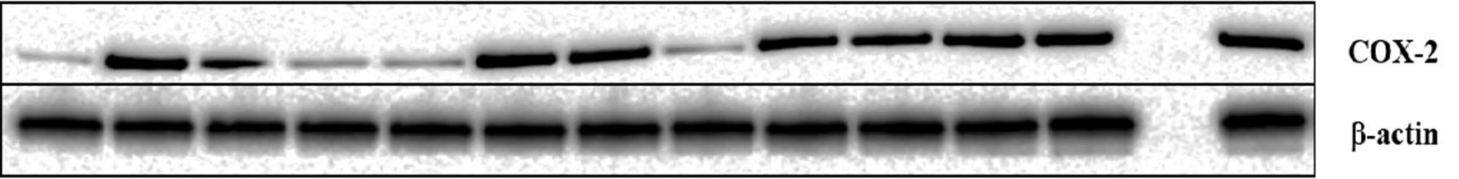

DMSO LPS VH02 Melo VH07 VH04 VH03 VH08 VH06 VH11 VH13 VH15 VH16

$+\operatorname{LPS} 5 \mu \mathrm{g} / \mathrm{mL}$
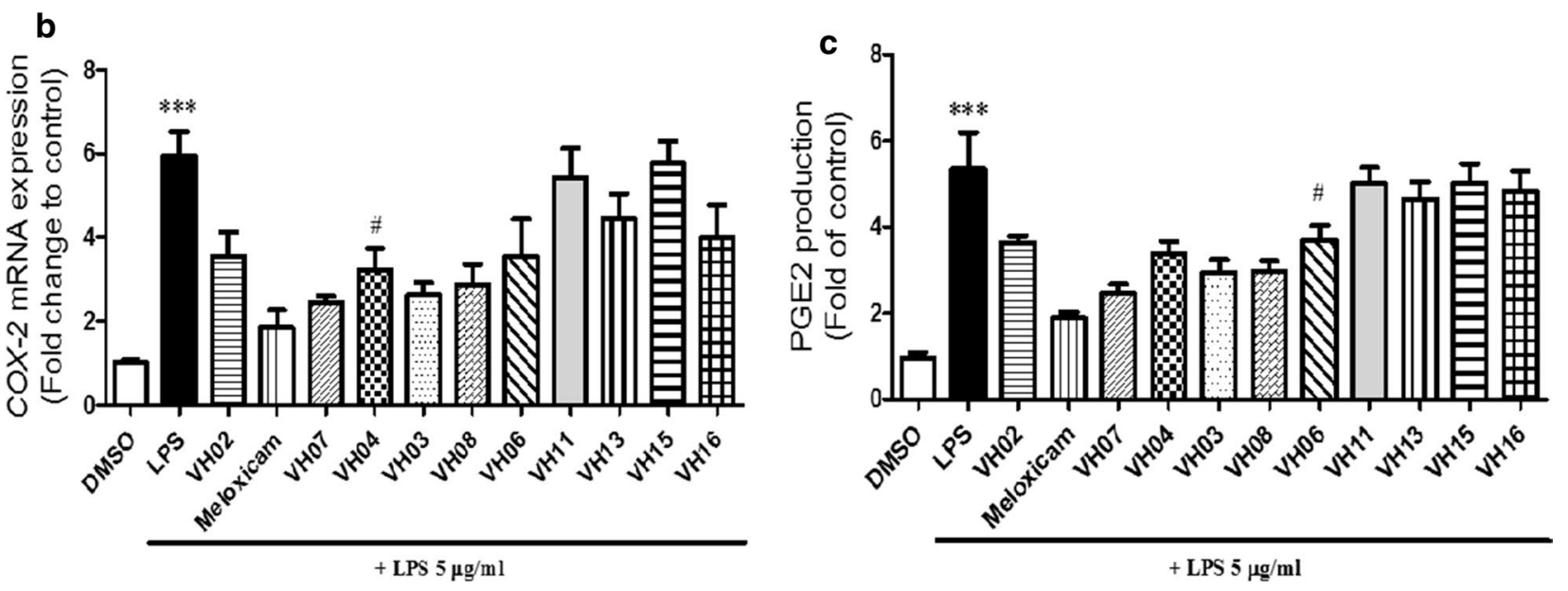

Fig. 3 Comparison of COX-2 protein expression effects of compounds from $V$. heyneana. $18 \mathrm{~h}$ after treating cells with $\mathrm{LPS}(5 \mu \mathrm{g} / \mathrm{mL})$ with or without compounds in RAW 264.7 cells, samples were harvested and lysated to immunoblottings with COX-2 and $\beta$-actin antibodies. b COX-2 mRNA level by qCPR $\left({ }^{* * *}\right.$ significant as compared to control, ${ }^{*} p<0.05$; ${ }^{*}$ significant as compared to LPS group, $\mathrm{n}=5$. c Comparison of PGE2 production effects of all compounds (10 M). RAW 264.7 cells were incubated with $5 \mu \mathrm{g} / \mathrm{mL}$ LPS for $18 \mathrm{~h}$ with or without compounds and amount of PGE2 in medium was determined using PGE2-specific ELISA assays ${ }^{* * *}$ significant as compared to control, ${ }^{*} p<0.05$; ${ }^{*}$ significant as compared to LPS group, $\mathrm{n}=5$. Codes:

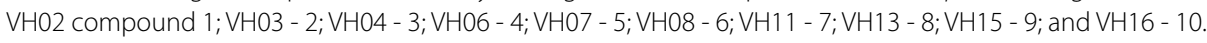

especially in quantitation protein and mRNA level of COX-2 by performing western blotting and real-time PCR. As shown in Fig. 4b and c, COX-2 levels were decreased by both of protein amount and mRNA levels. These results were also confirmed by dose dependent manner.

\section{Effect of 5 on NO productions and NF-KB activation}

As shown in Fig. 5a, 5 (Code VH07, 1-30 $\mu \mathrm{M}$ ) significantly inhibited LPS-induced NO production in a dose dependent manner. Especially, at the highest concentration $(30 \mu \mathrm{M})$, this compound could decrease the amount of $\mathrm{NO}$ production more than 2-fold compared to unstimulated vehicle. Since NF-кB was identified as an important transcription factor that controls several pro-inflammatory mediations, we investigated the NF- $\mathrm{kB}$ transcription activity by performing luciferase reporter gene assay and the results are shown in Fig. 5b. Compound $5(1-30 \mu \mathrm{g} / \mathrm{mL})$ dose dependent reduced LPSinduced NF- $\mathrm{kB}$ transitivity $(p<0.05)$.

\section{Discussion}

Vitis sp. is widely distributed and has been used as the raw material for juice and wine all over the world. For the pharmaceutical application, it has been reported that the roots, stems and leaves possessed anti-inflammatory, antioxidants, and anti-tumour activities, and contains a number of stilbenoid and resveratrol oligomers. Previously, resveratrol (3,4',5-trihydroxystilbene) isolated mostly from Vitis sp. as a main metabolite with high concentration, was shown to play an important role in human health with extremely extensive bioactivities such as anti-bacterial, anti-thrombotic, anti-oxidation, anti-inflammatory, reduce hypertension, and especially anti-cancer [9-13]. In addition, several studies focused on resveratrol oligomers that are characterized by the polymerization of several resveratrol units [9-13]. In this study, we demonstrated the potential involvement of the NF- $\mathrm{BB}$ pathway in the anti-inflammation of metabolites from $V$. heyneana. Among the active components, 5 was found to be the most anti-inflammatory activity 
a

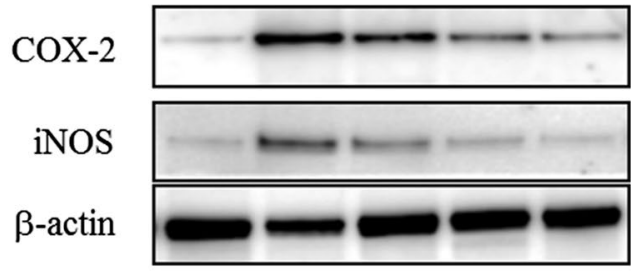

VH07 $(\mu \mathrm{M}) \quad-\quad-\quad 1 \quad 3 \quad 10$

LPS $5 \mu \mathrm{g} / \mathrm{ml} \quad-\quad+\quad+\quad+$
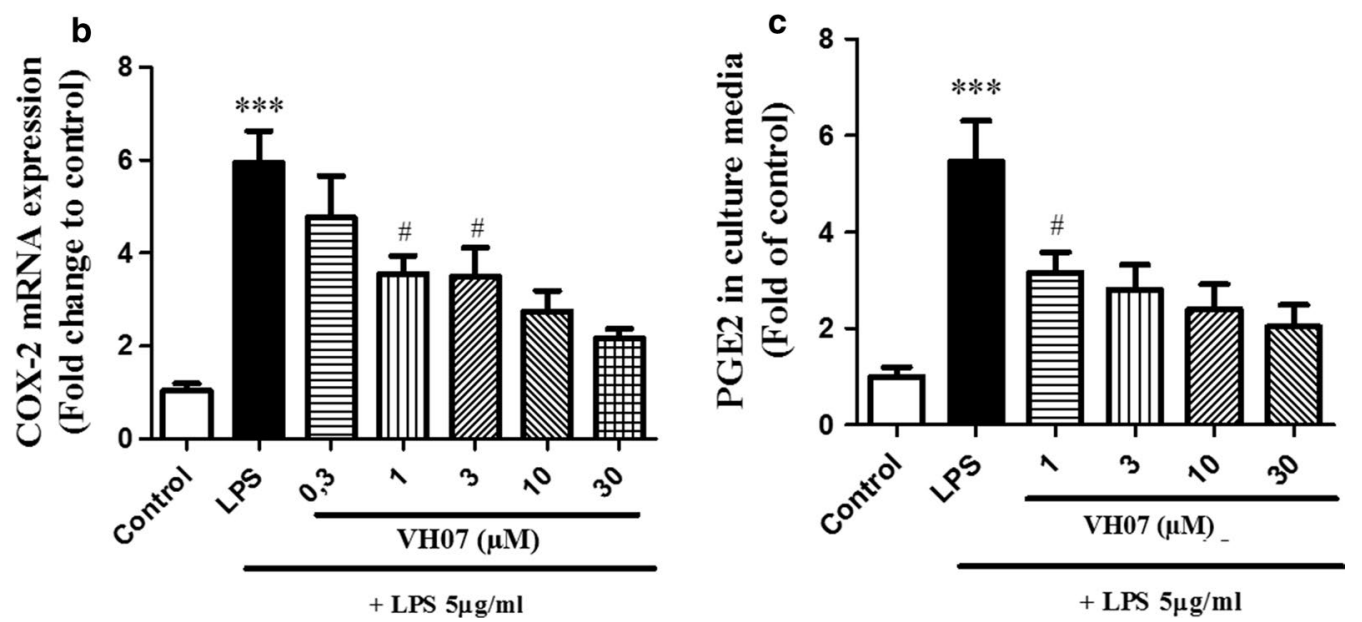

Fig. 4 Effect of 5 on COX-2 and iNOS expression in dose-dependent manner (1-30 $\mu \mathrm{M})$. Raw264.7 cells were treated with $5 \mu \mathrm{g} / \mathrm{mL} L \mathrm{LPS}$ for $18 \mathrm{~h}$ with or without $\mathrm{VH} 07$ and then harvested and lysated to immunoblottings with COX-2, iNOS and $\beta$-actin antibodies. $\mathbf{b}$ Effect of $\mathbf{5}$ on LPS-induced COX-2 was analyzed by qPCR (***significant as compared to control, ${ }^{*} p<0.05$; ${ }^{*}$ significant as compared to LPS group, $\left.n=5\right)$. $\mathbf{c}$ Effect of $\mathbf{5}$ on PGE2 production. RAW 264.7 cells were incubated with $5 \mu \mathrm{g} / \mathrm{mL}$ LPS for $18 \mathrm{~h}$ with or without $\mathbf{5}$ and amounts of PGE2 in medium was determined using PGE2-specific ELISA assays. (***significant as compared to control, ${ }^{*} p<0.05$; ${ }^{*}$ significant as compared to LPS group, $n=4$ )
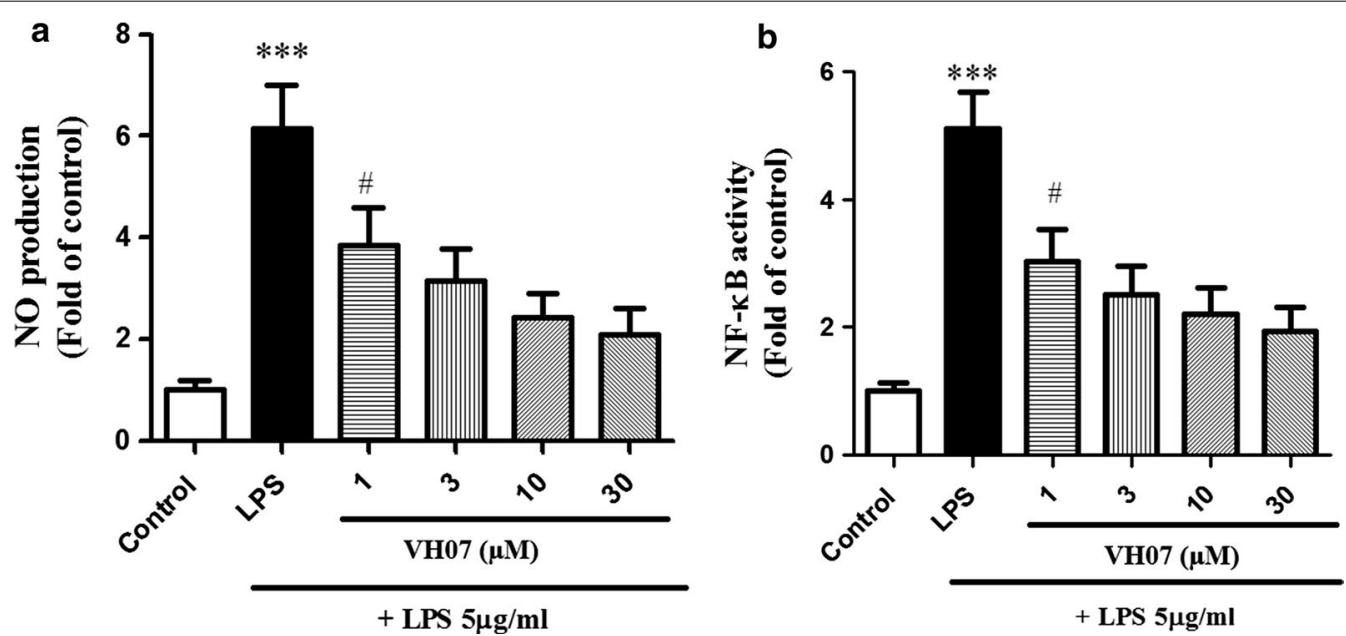

Fig. 5 Compound $\mathbf{5}$ (VH07) reduced LPS-induced NO production and NF-KB activity in RAW 264.7 macrophages in a dose-dependent manner. ${ }^{* * *}$ significant as compared to control, ${ }^{*} p<0.05$; ${ }^{*}$ significant as compared to LPS group, $n=4$ 
in suppression of NO, PGE2, and COX-2 production in LPS-stimulated RAW 264.7 macrophage cells. We also found that, this oligostilbenoid inhibited LPS-induced NF- $k B$ activation.

RAW 264.7 cells are the murine macrophage cells line that plays an important testable model for anti-inflammatory agent nowadays. When the macrophage cells were activated by LPS, a number of cytokines were released and recordable. Among them, $\mathrm{NO}$ is an inflammation mediator, in which, NO produced by iNOS coursed toxicity to cells and directly concern to the pathogenesis of inflammation process. COX-1 and COX-2 are the isozymes that convert arachidonic acid to prostaglandin, however, COX-2 responses mainly to produce a huge amount of PGEs in macrophage cells. Inhibition of the above productions may be the effective method for the treatment of several types of inflammation. Of our experiments, this is the first report confirming that oligostibene from $V$. heyneana suppresses the LPS-induced inflammatory response by activating NF- $\mathrm{KB}$ in vitro. $(-)$-Trans- $\varepsilon$-viniferin was first isolated from $V$. vinifera and classified as a model for its bio-synthesis from resveratrol. Similar to resveratrol, this dimer was shown to have several biological properties such as anti-oxidant, antidepressant, and anti-adipogenesis [27-30]. This compound showed cytotoxicity in several cancer cell lines as C6, Hep G2, HeLa, and MCF-7n and exerted the anti-proliferative and pro-apoptotic effect in U266, RPMI8226, Jurkat, K562 and U937 and other cancer cell lines [4, 31]. (-)-Trans- $\varepsilon$-viniferin and its derivative compounds slightly reduced cell proliferation on human adenocarcinoma colon cells and could constitute new putative anti-cancer agents on colon carcinoma [32]. (-)-Trans$\varepsilon$-viniferin significantly attenuated mutant $\mathrm{Htt}$-induced depletion of SIRT3 and protected cells from mutant Htt. This compound also decreased levels of reactive oxygen species and prevented loss of mitochondrial membrane potential in cells expressing mutant $\mathrm{Htt}$ [33]. The other form, $\alpha$-viniferin, also down-regulated the LPS-induced expression of pro-inflammatory genes such as iNOS and COX-2 by suppressing the activity of NF- $\mathrm{kB}$ via dephosphorylation of Akt/PI3K. This compound suppressed NO and PGE2 production in the late stage of inflammation through induction of heme oxygenase- 1 (HO-1), and the expression of pro-inflammatory genes iNOS and COX-2 in the early stage of inflammation by inhibiting the Akt/ PI3K-dependent NF- $\mathrm{kB}$ activation in BV2 microglial cells [34]. The $V$. thunbergii extract that was rich in (-)-trans$\varepsilon$-viniferin significantly inhibited PGE2 production in LPS-induced PHCs cells without exhibiting significant cytotoxicity [35].

Even though (-)-trans- $\varepsilon$-viniferin and its isomers have been shown to have several anti-inflammatory effects, the molecular mechanism underlying the anti-inflammatory in LPS-induced RAW 264.7 has not been completely elucidated thus far. The results of our research indicate that among the active components, treating the RAW 264.7 macrophage cells with several concentrations of (-)-trans- $\varepsilon$-viniferin (5) could inhibit LPS-induced NO, PGE2, iNOS, COX-2 productions in a dose dependent manner. With the highest concentration at $30 \mu \mathrm{M}$, this oligostibene significantly reduced the above productions more than $50 \%$ as compared to the LPS-treated cell alone.

\section{Methods \\ Plant materials}

The aerial parts of $V$. heyneana were collected from Lao Cai province (north of Vietnam) in September 2016 and botanically identified by Assoc. Prof. Dr. Nguyen The Cuong, Institute of Ecology and Biological Resources. A voucher specimen (TL07) has been deposited at the Herbarium of IEBR and Department of Phytochemistry, Hanoi, Vietnam.

\section{General experiment procedures}

Melting points were determined on an Electrothermal apparatus. Optical rotations were measured on a JASCO V-550 UV/Vis spectrometer (Tokyo, Japan). The NMR $\left[{ }^{1} \mathrm{H}(500 \mathrm{MHz}),{ }^{13} \mathrm{C}(125 \mathrm{MHz})\right]$ experiments were performed on a Bruker Advance 500 spectrometer (United State). Chemical shift was reported in ppm downfield from TMS, with $J$ in $\mathrm{Hz}$. Mass spectra were obtained with an AGILENT 1200 series LC-MSD Ion Trap (United State). Analytical TLC was performed on Kieselgel 60 $\mathrm{F}_{254}$ (Merck) plates (silica gel, $0.25 \mathrm{~mm}$ layer thickness) and RP-18 $\mathrm{F}_{254}$ (Merck) plates (0.25 mm layer thickness). UV spots were visualized using ultraviolet irradiation (at $254-365 \mathrm{~nm}$ ) and by spraying with $10 \% \mathrm{H}_{2} \mathrm{SO}_{4}$, followed by heating with a heat gun. Column chromatography was performed on silica gel (70-230 and 230-400 mesh, Merck), YMC RP-18 resin (30-50 $\mu \mathrm{m}$, Fuji Silysia Chemical Ltd.), and Sephadex ${ }^{\text {TM }}$ LH-20 columns (Amersham Biosciences, Uppsala, Sweden). Dulbecco's modified Eagle's medium (DMEM), trypsin and fetal bovine serum (FBS) were purchased from Gibco BRL (Grand Island, NY). COX-2 (1:1000, Cat: 610204) was obtained from BD Biosciences. Secondary mouse or rabbit HRP-conjugated antibodies (1:5000 or 1:10,000, Cell Signaling, \#7074, \#7076). $\beta$-actin (Cat: A5316), LPS (Cat: L4391), meloxicam (cat: M3935) and MTT (cat: M2128) were purchased from Sigma-Aldrich.

\section{Cell culture}

RAW 264.7 cells were purchased from the American Type Culture Collection (ATCC, Rockville, MD). Cells 
were cultured and growth in DMEM (Gibco) medium containing $10 \%$ fetal Bovine Serum (FBS) (Gibco), 100 units $/ \mathrm{mL}$ penicillin, and $100 \mu \mathrm{g} / \mathrm{mL}$ streptomycin at $37{ }^{\circ} \mathrm{C}$ in $5 \% \mathrm{CO}_{2}-95 \%$ air. Penicillin and streptomycin were obtained from Biochrom.

\section{Western blot analysis}

RAW 264.7 cells were seeded in 6 well-plate and treated with extractions or compounds from $V$. heyneana. Cells were collected and washed with cold phosphate-buffered saline (PBS). The collected cells were lysed on ice for $30 \mathrm{~min}$ in $100 \mu \mathrm{L}$ lysis buffer [ $120 \mathrm{mM} \mathrm{NaCl}, 40 \mathrm{mM}$ Tris (pH 8), 0.1\% NP40 (Nonidet P-40)] and centrifuged at 12,000 rpm for $30 \mathrm{~min}$. BCA protein assay kit (Pierce, Rockford, IL) was used to measure protein concentrations as described in a previous report [36]. Finally, bands were detected by ECL kit (Pierce West Femto), and images were acquired using the Odyssey Fc Imager (LICOR Biosciences).

\section{Quantitative real-time PCR (qRT-PCR)}

Total RNA was isolated using Trizol (Takara, Japan) according to the manufacturer's instructions. COX-2 mRNA expression was analyzed by real-time qPCR (StepOnePlus qPCR cycler, Applied Biosystems) using QuantiFast SYBR Green RT-PCR Kit Qiagen, (\#204156) and primers (Qiagen): COX-2 (Ptgs2) (Cat: QT00165347), Mm_GADPH (Cat: QT01658692).

\section{Measurement of nitrite}

RAW 264.7 cells $\left(5 \times 10^{5}\right.$ cells $)$ were pre-incubated at $37^{\circ} \mathrm{C}$ for $12 \mathrm{~h}$ in serum-free medium and NO production was monitored by measuring nitrite levels in culture media using Griess reagent (1\% sulfanilamide, $0.1 \%$ $\mathrm{N}$-1-naphthylenediamine dihydrochloride, and 2.5\% phosphoric acid). Absorbance was measured at $540 \mathrm{~nm}$ after incubating for $10 \mathrm{~min}$.

\section{Reporter gene assay}

One $\mu \mathrm{g}$ of the plasmid NF-kB or $50 \mathrm{ng}$ of pRL Renilla was transfected into the cells using LipofectAMINE2000 (Invitrogen Corp., Carlsbad, CA) using the Dual-Luciferase Reporter Assay Systems (Promega, Madison, WI, USA). After $6 \mathrm{~h}$, the transfection medium was replaced with the DMEM without serum and the cells were further incubated for $18 \mathrm{~h}$. The firefly and hRenilla luciferase activity was detected using a multilaber counter. Ratio of activity was determined by normalizing the promoterdriven luciferase activity versus hRenilla luciferase.

\section{Enzyme-linked immunosorbent assay (ELISA)}

Prostaglandin E2 (PGE2) concentrations in DMEM media were measured by ELISA kit (Cayman
Chemical, Ann Arbor, MI) according to the manufacturer's protocols.

\section{Extraction and isolation}

The aerial part of $V$. heyneana $(5.0 \mathrm{~kg})$ was extracted with $\mathrm{EtOH} 96 \%(3 \mathrm{~h} \times 3 \mathrm{~L})$ at $50{ }^{\circ} \mathrm{C}$. The combined extracts were filtered and evaporated under pressure to give green residue $(235.5 \mathrm{~g})$ which was suspended in water and partitioned with organic solvent to get $n$-hexane $(26.05 \mathrm{~g})$, EtOAc $(129.67 \mathrm{~g})$, and aqueous extract (50.4 g), successfully. The EtOAc extract $(34.0 \mathrm{~g})$ was initially chromatographed on a silica gel column (63-200 $\mu \mathrm{M}$ particle size, Merck) eluting with a stepwise gradient of methylene chloride (MC)-MeOH (from 100:1 to 1:100) to yield seven fractions (VHE1-VHE7). Fraction VHE4 $(1.5 \mathrm{~g})$ was fractionated by normal-phase silica gel CC (40-63 $\mu \mathrm{M}$ particle size, Merck) eluted with $\mathrm{MC}-\mathrm{MeOH}$ (20:1) to obtain compound 3 (13 mg) and five smaller fractions (VHE4.1-VHE4.5). Fraction VHE4.3 Fraction VHE4.4 (500 mg) was subjected to Sephadex eluted with a mixture of $\mathrm{MeOH}-\mathrm{H}_{2} \mathrm{O}(2: 1)$ to give $4(23 \mathrm{mg})$ and 5 (40 mg). Fraction VHE5 (3.5 g) was isolated by silica gel $\mathrm{CC}$ with elution mixture of $\mathrm{MC}-\mathrm{MeOH}(15: 1)$ to yield ten sub-fractions (VHE5.1-VHE5.10). Compound 6 (25 mg) was purified from fraction VHE5.3 (400 $\mathrm{mg}$ ) by using Sephadex LH-20 eluting with $\mathrm{MeOH}-\mathrm{H}_{2} \mathrm{O}$ (5:1). Fraction VHE5.4 (1.1 g) was applied to RP-C18 gel CC using a gradient mixture of $\mathrm{MeOH}-\mathrm{H}_{2} \mathrm{O}$ (from 1:2 to 2:1) to obtain $7(25 \mathrm{mg}), 8(22 \mathrm{mg})$, and $9(13 \mathrm{mg})$ and eight fractions (VHE5.4.1-VHE5.4.8). Compound 10 (14 mg) was purified from fraction VHE5.4.5 (300 mg) by using MCI gel CC eluting with $\mathrm{MeOH}-\mathrm{H}_{2} \mathrm{O}$ (3:2). Fraction VHE6 (1.3 g) was separated on Sephadex gel CC eluting with $\mathrm{MeOH}$ $\mathrm{H}_{2} \mathrm{O}$ (3:2) to yield 1 (12 mg), and 2 (25 mg). Structural identification of the isolated compounds $\mathbf{1}-\mathbf{1 0}$ have been previously published by our group [37, 38].

(-)-Trans- $\varepsilon$-viniferin (5): Grey-brown solid; mp150$152{ }^{\circ} \mathrm{C}$, soluble in ethanol, methanol, and acetone; $[\alpha]_{\mathrm{D}}^{25}-47.0(c=0.5, \mathrm{MeOH}) ; \mathrm{R}_{f}=0,64$ (TLC, silica gel, dichlomethane-methanol 7:1, v/v). ${ }^{1} \mathrm{H}-\mathrm{NMR}(500 \mathrm{MHz}$, acetone- $\left.d_{6}\right), \delta_{\mathrm{H}}(\mathrm{ppm}): 7.20(2 \mathrm{H}, d, J=8.5 \mathrm{~Hz}, \mathrm{H}-2,6), 7.17$ $\left(2 \mathrm{H}, d, J=8.5 \mathrm{~Hz}, \mathrm{H}-2^{\prime}, 6^{\prime}\right), 6.90\left(1 \mathrm{H}, d, J=16.5, \mathrm{H}-7^{\prime}\right)$, $6.83(2 \mathrm{H}, d, J=8.5 \mathrm{~Hz}, \mathrm{H}-3,5), 6.73(2 \mathrm{H}, d, J=9.0 \mathrm{~Hz}$, $\left.\mathrm{H}-3^{\prime}, 5^{\prime}\right), 6.72\left(1 \mathrm{H}\right.$, brs, $\left.\mathrm{H}-14^{\prime}\right), 6.71(1 \mathrm{H}, d, J=16.5 \mathrm{~Hz}$, $\left.\mathrm{H}-8^{\prime}\right), 6.33\left(1 \mathrm{H}, d, J=2,0 \mathrm{~Hz}, \mathrm{H}-12^{\prime}\right), 6.24(3 \mathrm{H}, \mathrm{s}, \mathrm{H}-10,12$, 14), $5.42(1 \mathrm{H}, d, J=5.5 \mathrm{~Hz}, \mathrm{H}-7), 4.47(1 \mathrm{H}, d, J=5.5 \mathrm{~Hz}$, $\mathrm{H}-8) ;{ }^{13} \mathrm{C}-\mathrm{NMR}\left(125 \mathrm{MHz}\right.$, acetone- $\left.d_{6}\right), \delta_{\mathrm{C}}(\mathrm{ppm}): 162.5$ (C-11'), 159.9 (C-11, 13), $159.6\left(\mathrm{C}-13^{\prime}\right), 158.2\left(\mathrm{C}-4,4^{\prime}\right)$, 147.4 (C-9), $136.4\left(\mathrm{C}-9^{\prime}\right), 133.9$ (C-1), $130.1\left(\mathrm{C}-7^{\prime}\right), 129.9$ (C-1'), $128.7\left(\mathrm{C}-2^{\prime}, 6^{\prime}\right), 127.9(\mathrm{C}-2,6), 123.5\left(\mathrm{C}-8^{\prime}\right), 119.8$ (C-10'), $\left.116.3\left(\mathrm{C}-3^{\prime}, 5^{\prime}\right), 116.2(\mathrm{C}-3,5), 107.0(\mathrm{C}-10,14)\right)$, 104.2 (C-14'), 102.1 (C-12), 96.8 (C-12'), 93.9 (C-7), 57.1 (C-8). ESI-MS $m / z: 477[\mathrm{M}+\mathrm{Na}]^{+}$. 


\section{Statistics}

Values are presented as mean \pm SE unless otherwise stated. $P$-values were calculated by Student's $t$ test or one-way analysis of variance followed by Bonferroni post hoc testing using GraphPad Prism 5 (GraphPad Software Inc.). $P<0.05$ was considered statistically significant. Data are expressed as mean \pm SEM. *, $p<0.05$; **, $p<0.01 ; * * *, p<0.001$.

\section{Conclusion}

This the first time that a Vietnamese $V$. heyneana extract and its phytochemical constituents have been reported to possess an anti-inflammatory activity. The results demonstrated that one of the most active compounds, (-)-trans- $\varepsilon$-viniferin, decreased NO, PGE2, iNOS, and COX-2 productions in RAW 264.7 macrophage cells after LPS stimulation. This anti-inflammatory activity may mediate by the NF- $\mathrm{kB}$ activation mechanism in the RAW 264.7 cells. However, to imply that this Vitis sp. and its components may be useful in the prevention or treatment of inflammatory diseases may be premature as further studies and confirmation of these results are required.

\section{Authors' contributions}

DTH, TTH conceived and designed the study. PTL, NTTA, LTL, HVO completed the extraction, isolation and identified the chemical structures of all isolated compounds. DTT, TMH and NMK carried out the biological experiments, data analysis. TMH, TTH and DTH drafted the manuscript. All authors read and approved the final manuscript.

\begin{abstract}
Author details
1 Vietnam National Institute of Medicinal Materials, 3B Quangtrung, Hanoi, Vietnam. ${ }^{2}$ Department of Experimental Medical Science, Faculty of Medicine, Lund University, BMC D12, 22184 Lund, Sweden. ${ }^{3}$ Thai Binh University of Medicine and Pharmacy, Thai Binh City, Vietnam. ${ }^{4}$ Department of Plant and Environmental Sciences, University of Copenhagen, Copenhagen, Denmark. ${ }^{5}$ Research Institute of Pharmaceutical Sciences, College of Pharmacy, Kyungpook National University, Daegu 41556, Republic of Korea. ${ }^{6}$ Hanoi University of Pharmacy, 13 Le Thanh Tong, Hoan Kiem district, Hanoi 100100, Vietnam. ${ }^{7}$ Department of Biomedical Sciences, Institute for Research and Executive Education (VNUK), The University of Danang, 41 Le Duan, Haichau district, Danang 551000, Vietnam.
\end{abstract}

\section{Acknowledgements}

This work was assisted by a grant from Vietnam National Foundation for Science and Technology Development (NAFOSTED: 106.YS.05-2014.26).

\section{Competing interests}

The authors declare that they have no competing interests.

\section{Availability of data and materials}

Not applicable.

\section{Consent for publication \\ Not applicable.}

Ethics approval and consent to participate

Not applicable.

\section{Funding}

Vietnam National Foundation for Science and Technology Development.

\section{Publisher's Note}

Springer Nature remains neutral with regard to jurisdictional claims in published maps and institutional affiliations.

Received: 21 August 2017 Accepted: 7 February 2018

Published online: 13 February 2018

\section{References}

1. Royal Botanic Gardens Kew (2013) The plant list: Vitis. http://www. theplantlist.org/browse/A/Vitaceae/Vitis/. Accessed May 2017

2. Cuong NT (2012) Study on classification of Vitaceae Juss. in Vietnam, Dissertation of Biology, Institute of Ecology \& Biological Recourse, Vietnam Academy of Science \& Technology

3. Ha DT, Kim H, Thuong PT, Ngoc TM, Lee I, Hung ND, Bae K (2009) Antioxidant and lipoxygenase inhibitory activity of oligostilbenes from the leaf and stem of Vitis amurensis. J Ethnopharmacol 125(2):304-309

4. Ha DT, Chen QC, Hung TM, Youn UJ, Ngoc TM, Thuong PT, Kim HJ, Seong YH, Min BS, Bae K (2009) Stilbenes and oligostilbenes from leaf and stem of Vitis amurensis and their cytotoxic activity. Arch Pharm Res 32(2):177-183

5. Chiou WF, Shen CC, Chen CC, Lin CH, Huang YL (2009) Oligostilbenes from the roots of Vitis thunbergii. Planta Med 75(8):856-859

6. Nassiri-Asl M, Hosseinzadeh H (2016) Review of the pharmacological effects of Vitis vinifera (Grape) and its bioactive constituents: an update. Phytother Res 30(9):1392-1403

7. Pawlus AD, Sahli R, Bisson J, Rivière C, Delaunay JC, Richard T, Gomès E, Bordenave L, Waffo-Téguo P, Mérillon JM (2013) Stilbenoid profiles of canes from Vitis and Muscadinia species. J Agric Food Chem 61(3):501-511

8. Keller M (2010) The science of grapevines: anatomy and physiology. Academic Press, London, p 400p

9. Soejima A, Wen J (2006) Phylogenetic analysis of the grape family (Vitaceae) based on three chloroplast markers. Am J Bot 93:278-287

10. Roupe KA, Remsberg CM, Yáñez JA, Davies NM (2006) Pharmacometrics of stilbenes: seguing towards the clinic. Curr Clin Pharmacol 1(1):81-101

11. Bertelli AA, Das DK (2009) Grapes, wines, resveratrol, and heart health. J Cardiovasc Pharmacol 54(6):468-476

12. Vidavalur R, Otani H, Singal PK, Maulik N (2006) Significance of wine and resveratrol in cardiovascular disease: french paradox revisited. Exp Clin Cardiol 11:217-225

13. Pezzuto JM (2008) Grapes and human health: a perspective. J Agric Food Chem 56:6777-6784

14. Dinicola S, Cucina A, Antonacci D, Bizzarri M (2014) Anticancer effects of grape seed extract on human cancers: a review. J Carcinog Mutagen S 8:005

15. Alison DP, Pierre WWT, Jonah S, Merillon JM (2012) Stilbenoid chemistry from wine and the genus Vitis, a review. J Int Sci Vigne Vin 46(2):57-111

16. Long PT, An NTT, Ha DT, Tuan DT, Dung LV (2017) Some stilbenoids isolated from the ethyl acetate fractions of Vitis heyneana Roem. \& Schult. Pharmaceutical J 57(493):59-64

17. Chi VV (2012) Dictionary of Vietnam medicinal plants, vol 2. Medical Publishing House, Hanoi, p 356-357

18. Li WW, Ding LS, Li BG, Chen YZ (1996) Oligostilbenoids from Vitis heyneana. Phytochemistry 42(4):1163-1165

19. Li Y, Li ZH, Zhang CH, Zhang XD, Cui ZH (2013) Chemical constituents from Vitis heyneana Roem. \& Schult. Biochem Syst Ecol 50:266-268

20. Teguo PW, Decendit A, Vercauteren J, Vercauteren J, Deffieux G, Mérillon JM (1996) Trans-resveratrol-3-O- $\beta$-glucoside (piceid) in cell suspension cultures of Vitis vinifera. Phytochemistry 42(6):1591-1593

21. Korhammer S, Reniero F, Mattivi F (1995) An oligostilbene from Vitis roots. Phytochemistry 38:1501-1504

22. Li W, Li B, Chen Y (1998) Oligostilbenes from Vitis betulifolia. Phytochemistry 49:1393-1394

23. Huang YL, Tsai WJ, Shen CC, Chen CC (2005) Resveratrol derivatives from the roots of Vitis thunbergii. J Nat Prod 68(2):217-220

24. Kitanaka S, Ikezawa T, Yasukawa K, Yamanouchi S, Takido M, Sung HK, Kim IH (1990) (+)-a-viniferin, an anti-inflammatory compound from Caragana chamlagu root. Chem Pharm Bull 38(2):432-435 
25. Ito T, Furusawa M, Iliya I, Tanaka T, Nakaya KI, Sawa R, Kubota Y, Takahashi Y, Riswan S, linuma M (2005) Rotational isomerism of a resveratrol tetramer, shoreaketone, Shorea uliginosa. Tetrahedron Lett 46(17):3111-3114

26. Huang KS, Lin M (1999) Oligostilbenes from the roots of Vitis amurensis. J Asian Nat Prod Res 2(1):21-28

27. Privat C, Telo JP, Bernardes-Genisson V, Vieira A, Souchard JP, Nepveu F (2002) Antioxidant properties of trans-epsilon-viniferin as compared to stilbene derivatives in aqueous and nonaqueous media. J Agric Food Chem 50(5):1213-1217

28. Yáñez M, Fraiz N, Cano E, Orallo F (2006) (-)-Trans-epsilon-viniferin, a polyphenol present in wines, is an inhibitor of noradrenaline and 5-hydroxytryptamine uptake and of monoamine oxidase activity. Eur J Pharmacol 542(1-3):54-60

29. Ohara K, Kusano K, Kitao S, Yanai T, Takata R, Kanauchi O (2015) $\varepsilon$-viniferin, a resveratrol dimer, prevents diet-induced obesity in mice. Biochem Biophys Res Commun 468(4):877-882

30. Billard C, Izard JC, Roman V, Kern C, Mathiot C, Mentz F, Kolb JP (2002) Comparative antiproliferative and apoptotic effects of resveratrol, epsilon-viniferin and vine-shots derived polyphenols (vineatrols) on chronic B lymphocytic leukemia cells and normal human lymphocytes. Leuk Lymphoma 43(10):1991-2002

31. Giovannelli L, Innocenti M, Santamaria AR, Bigagli E, Pasqua G, Mulinacc N (2014) Antitumoural activity of viniferin-enriched extracts from Vitis vinifera L. cell cultures. Nat Prod Res 28(22):2006-2016

32. Marel AK, Lizard G, Izard JC, Latruffe N, Delmas D (2008) Inhibitory effects of trans-resveratrol analogs molecules on the proliferation and the cell cycle progression of human colon tumoral cells. Mol Nutr Food Res 52(5):538-548

33. Fu J, Jin J, Cichewicz RH, Hageman SA, Ellis TK, Xiang L, Peng Q, Jiang M, Arbez N, Hotaling K, Ross CA, Duan W (2012) Trans-(-)- $\varepsilon$-viniferin increases mitochondrial sirtuin 3 (SIRT3), activates AMP-activated protein kinase (AMPK), and protects cells in models of Huntington Disease. J Biol Chem 287(29):24460-24472

34. Dilshara MG, Lee KT, Kim HJ, Lee HJ, Choi YH, Lee CM, Kim LK, Kim GY (2014) Anti-inflammatory mechanism of a-viniferin regulates lipopolysaccharide-induced release of proinflammatory mediators in BV2 microglial cells. Cell Immunol 290(1):21-29

35. Tsai CF, Wang KT, Chen LG, Lee CJ, Tseng SH, Wang CC (2014) Antiinflammatory effects of Vitis thunbergii var. taiwaniana on knee damage associated with arthritis. J Med Food 17(4):479-486

36. Ha DT, Oh J, Khoi NM, Dao TT, le Dung V, Do TN, Lee SM, Jang TS, Jeong GS, Na M (2013) In vitro and in vivo hepatoprotective effect of ganodermanontriol against t-BHP-induced oxidative stress. J Ethnopharmacol 150(3):875-885

37. Long PT, An NTT, Ha DT, Tuan DT, Oanh HV, Dung LV (2017) Some stilbenoids isolated from the ethyl acetate fractions of Vitis heyneana Roem \& Schult. Pharmaceutical J 493(57):59-63

38. Long PT, An NTT, Thuy PT, Oanh HV, Khoi NM, Ha DT Oligostilbenoids isolated from the ethyl acetate fractions of Vitis heyneana Roem \& Schult. J Med Mat 22(6): 352-352-360

\section{Submit your manuscript to a SpringerOpen ${ }^{\circ}$ journal and benefit from:}

- Convenient online submission

$\checkmark$ Rigorous peer review

- Open access: articles freely available online

- High visibility within the field

- Retaining the copyright to your article

Submit your next manuscript at $\boldsymbol{\nabla}$ springeropen.com 